\section{Differential Resistance of Gordonieae Trees to Phytophthora cinnamomi}

\author{
Elisabeth M. Meyer ${ }^{1}$, Thomas G. Ranney ${ }^{2,5}$, and Thomas A. Eaker ${ }^{3}$
}

Department of Horticultural Science, Mountain Horticultural Crops Research and Extension Center, North Carolina State University, 455 Research Drive, Fletcher, NC 28732

\begin{abstract}
Kelly Ivors ${ }^{4}$
Department of Plant Pathology, Mountain Horticultural Crops Research and Extension Center, North Carolina State University, 455 Research Drive, Mills River, NC 28759
\end{abstract}

Additional index words. host plant resistance, disease resistance, Abies fraseri, Franklinia alatamaha, Gordonia lasianthus, $\times$ Gordlinia grandiflora, $\times$ Schimlinia floribunda, Schima wallichii, Schima khasiana, Phytophthora cinnamomi

\begin{abstract}
Trees in the Theaceae tribe Gordonieae are valuable nursery crops, but some of these taxa are known to be highly susceptible to root rot caused by Phytophthora cinnamomi Rands. The objective of this study was to evaluate a collection of Gordonieae taxa for resistance to this pathogen. These taxa included Franklinia alatamaha Bart. Ex Marshall, Gordonia lasianthus (L.) Ellis, Schima wallichii Choisy, S. khasiana Dyer, $\times$ Schimlinia floribunda Ranney \& Fantz, and $\times$ Gordlinia grandiflora Ranney \& Fantz. Abies fraseri (Pursh) Poir. was also included in the study as a positive control. Containergrown trees were inoculated with three isolates of $P$. cinnamomi and symptoms were rated over an 84-day period during the summer of 2008. Disease symptom ratings from 1 (healthy) to 4 (dead) were collected twice weekly and area under the disease progress curve (AUDPC) values were calculated. None of the $S$. khasiana or $S$. wallichii exhibited any root rot symptoms or mortality, whereas the remaining species showed symptoms of infection at varying levels over time. Symptoms in $F$. alatamaha and $A$. fraseri were apparent before other taxa, and mortality for both species reached $100 \%$ by the end of the experiment. Comparison of AUDPC values indicated that $F$. alatamaha was the most susceptible followed by $A$. fraseri. There was no significant difference in AUDPC among the more resistant taxa, including $G$. lasianthus, both $S$ chima species, and the intergeneric hybrids. Values for AUDPC in the hybrid taxa were similar to their more resistant parental genus, indicating that resistance to $P$. cinnamomi is a partially dominant trait in these plants. These results further suggest the potential to breed improved hybrids of Gordonieae trees with substantial resistance to $P$. cinnamomi.
\end{abstract}

Franklinia alatamaha, a member of the Theaceae tribe Gordonieae, has both ornamental and historical significance. It was first discovered by John and William Bartram in 1765 but is now considered to be extinct in the wild and is only maintained in cultivation (Fry, 2000). Franklinia, with its large, white flowers that bloom in the fall and bright red fall foliage, makes a unique and desirable

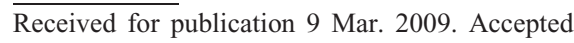
for publication 23 Apr. 2009.

This research was funded, in part, by the North Carolina Agricultural Research Service, Raleigh, NC.

Thanks are expressed to Joel Mowrey and Nathan Lynch for their technical assistance and to Dr. Anthony LeBude for assistance in propagating plants for this study.

This manuscript is from a thesis submitted by Elisabeth Meyer as partial fulfillment of the requirements for an MS degree.

${ }^{1}$ Graduate Research Assistant.

${ }^{2}$ Professor.

${ }^{3}$ Research Specialist.

${ }^{4}$ Assistant Professor.

${ }^{5}$ To whom reprint requests should be addressed; e-mail tom_ranney@ncsu.edu.
Successful crosses of Franklinia $\times$ Schima produced the intergeneric hybrid $\times$ Schimlinia (Ranney et al., 2003) and crosses of Franklinia $\times$ Gordonia produced the intergeneric hybrid $\times$ Gordlinia (Ranney and Fantz, 2006). However, little is known about the resistance of related species and potential parents to $P$. cinnamomi. The objective of this study was to evaluate a collection of species, clones, and hybrids of Franklinia, Gordonia, and Schima for resistance to P. cinnamomi.

\section{Materials and Methods}

During the summer of 2008, seven taxa of Gordonieae trees were inoculated with P. cinnamomi at the North Carolina State University Mountain Horticultural Crops Research Station in Mills River, NC. These taxa included $F$. alatamaha, G. lasianthus, $S$. khasiana, S. wallichii, $\times$ Gordlinia H2004024-008, $\times$ Schimlinia H2002-022-083, and $\times$ Schimlinia H2002-022-084. The plants of the selected Gordonieae taxa were 5-monthold rooted cuttings collected in early February of the same year. Two-year-old seedlings of $A$. fraseri were also included in the experiment as a positive control (Frampton and Benson, 2004). Plants of all taxa were grown in a $3: 1$ pine bark with peat (by volume) substrate amended with $1.8 \mathrm{~kg} \cdot \mathrm{m}^{-3}$ dolomitic limestone and $1.0 \mathrm{~kg} \cdot \mathrm{m}^{-3}$ micronutrients and top-dressed with $10 \mathrm{~g}$ of $15 \mathrm{~N}-$ 4P-10K controlled-release fertilizer (15-9-12 Osmocote ${ }^{\circledR}$ Plus 3-4 months; The Scott's Co., Marysville, $\mathrm{OH}$ ) in 3.8-L containers. For the duration of the experiment, plants were kept on a gravel container pad in an open-ended structure covered with white polyethylene providing $\approx 40 \%$ shade. Plants were watered by drip irrigation once daily for $5 \mathrm{~min}$.

Three isolates of $P$. cinnamomi were grown on sterile commercial rice grains in flasks in the dark at room temperature for $10 \mathrm{~d}$. The isolate accessions used as well as their host, country of origin, and year of isolation were: 2378 (fraser fir, Avery Co., NC, 1993), 2399 [Callitropsis $\times$ leylandii (A.B. Jacks. \& Dallim.) D.P. Little, Ashe Co., 1999], and two Hundley (fraser fir, Avery Co., 2005). On 27 June 2008, 10 individuals (replicates) from each taxon were inoculated with $P$. cinnamomi in a completely randomized design. Three rice grains from each of the three isolates were placed $4 \mathrm{~cm}$ below the surface of the media on opposite sides of the plant for each of the inoculated individuals. Five additional noninoculated plants of each taxon were maintained in a separate, completely randomized block under the same environmental and cultural conditions as negative controls. To prevent the spread of the pathogen, the gravel floor of the study site was covered with polyethylene, and any water draining from the site was collected and sterilized with bleach before being discarded.

Plants were monitored for symptoms of root rot every other week until symptoms occurred and thereafter rated twice a week. A scale from 1 to 4 , based on that described by Benson (1990), was used to rate the plants: 
1 = healthy, 2 = initial symptoms (flagging of new growth, chlorosis), 3 = severe symptoms (wilting, necrotic leaves), $4=$ dead. Plants were rated for $84 \mathrm{~d}$, at which point all plants exhibiting symptoms had died and all remaining plants appeared healthy. During the course of the study, nine root and stem segments, $\approx 1.3 \mathrm{~cm}$ in length, were excised from at least one of the dead plants for each taxon, surface-sterilized, and placed on three separate plates of selective $\mathrm{P}_{10} \mathrm{ARP}(\mathrm{H})$ media (Erwin and Ribeiro, 1996) to confirm the presence of the pathogen. This process was also performed on at least one inoculated plant of taxa that did not show any disease symptoms at the end of the study.

Area under the disease progress curve (AUDPC) values were calculated for each replicate in the experiment using the formula of Shaner and Finney (1977):

$$
\text { AUDPC }=\sum_{i=1}^{n}\left[\left(\mathrm{Y}_{\mathrm{i}+1}+\mathrm{Y}_{\mathrm{i}}\right) / 2\right]\left[\mathrm{X}_{\mathrm{i}+1}-\mathrm{X}_{\mathrm{i}}\right]
$$

where $\mathrm{Y}_{\mathrm{i}}=$ disease rating at the $i$ th observation, $\mathrm{X}_{\mathrm{i}}=$ days after inoculation at the $i$ th observation, and $n=$ the total number of observations. Disease ratings at specific dates and AUDPC values were subjected to analysis of variance and means separation using least significant difference (Proc GLM, SAS Version 9.1; SAS Institute, Cary, NC) to compare taxa.

\section{Results and Discussion}

The noninoculated control plants did not exhibit symptoms of infection by $P$. cinnamomi throughout the duration of the study (data not shown). Among the inoculated plants, none of the $S$. khasiana or S. wallichii exhibited symptoms, whereas the remaining taxa showed varying levels of infection (Fig. 1; Table 1). Symptoms in F. alatamaha and the susceptible control, A. fraseri, were apparent 28 and $42 \mathrm{~d}$ after inoculation, respectively, and mortality for both reached $100 \%$ by the end of the experiment $(84 \mathrm{~d}$ after inoculation). Symptoms in Gordonia, $\times$ Schimlinia, and $\times$ Gordlinia were generally delayed and less severe than in Franklinia and were not significantly different from the two species of Schima. When plant parts were harvested for reisolation of $P$. cinnamomi, roots of dead plants appeared brown and thinner in comparison with the white, fleshy roots of plants that did not exhibit any disease symptoms. Phytophthora cinnamomi was recovered from roots of inoculated plants in all taxa, including those taxa that appeared completely healthy at the end of the experiment, suggesting tolerance of the pathogen rather than total resistance.

The AUDPC, which reflects both rate of onset and severity of infection, also showed significant differences among taxa (Table 1). Franklinia alatamaha had the highest AUDPC followed by $A$. fraseri, a species known to be highly susceptible to $P$. cinnamomi. There was no significant difference among the AUDPC of G. lasianthus, both

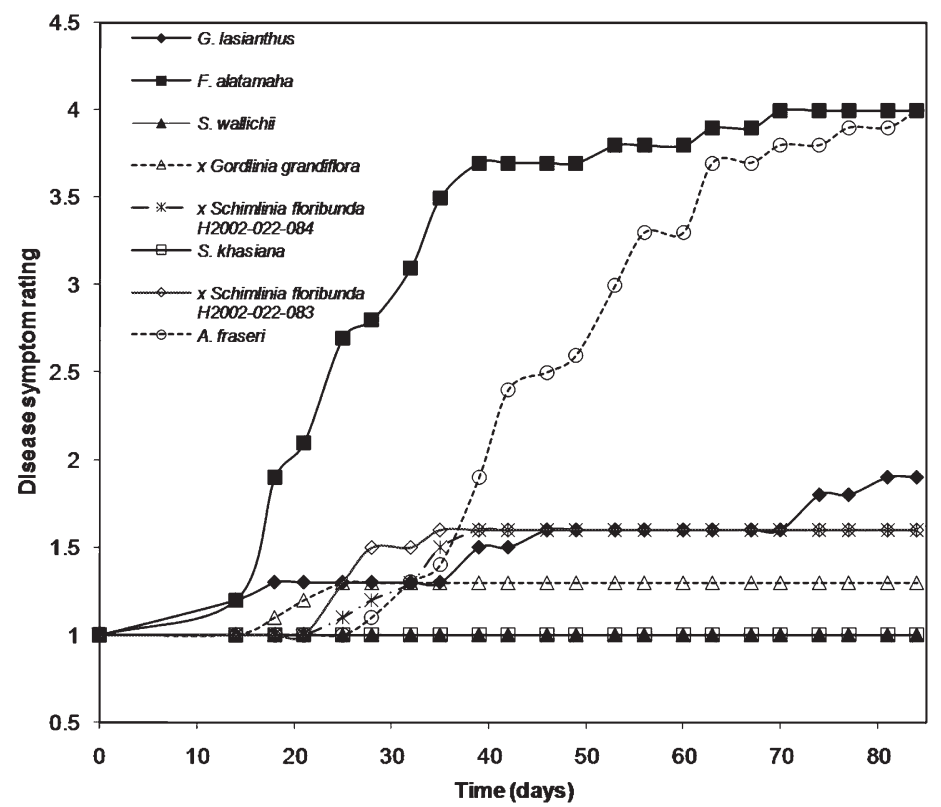

Fig. 1. Development of symptoms in Abies fraseri and selected taxa from the tribe Gordonieae after inoculation with Phytophthora cinnamomi.

Table 1. Disease symptom ratings and area under the disease progress curve (AUDPC) for Abies fraseri and selected taxa from the tribe Gordonieae after inoculation with Phytophthora cinnamomi.

\begin{tabular}{lcccccccc}
\hline & \multicolumn{7}{c}{ Disease symptom rating } & AUDPC $^{\mathrm{z}}$ \\
\cline { 2 - 8 } Taxa & Day 0 & Day 14 & Day 28 & Day 42 & Day 56 & Day 70 & Day 84 & (rating/d) \\
\hline F. alatamaha & $1.0^{\mathrm{x}} \mathrm{a}$ & $1.2 \mathrm{a}$ & $2.8 \mathrm{a}$ & $3.7 \mathrm{a}$ & $3.8 \mathrm{a}$ & $4.0 \mathrm{a}$ & $4.0 \mathrm{a}$ & $255.15 \mathrm{a}$ \\
A. fraseri & $1.0 \mathrm{a}$ & $1.0 \mathrm{a}$ & $1.1 \mathrm{~b}$ & $2.4 \mathrm{~b}$ & $3.3 \mathrm{a}$ & $3.8 \mathrm{a}$ & $4.0 \mathrm{a}$ & $192.10 \mathrm{~b}$ \\
G. lasianthus & $1.0 \mathrm{a}$ & $1.2 \mathrm{a}$ & $1.3 \mathrm{~b}$ & $1.5 \mathrm{c}$ & $1.6 \mathrm{~b}$ & $1.6 \mathrm{~b}$ & $1.9 \mathrm{~b}$ & $122.50 \mathrm{c}$ \\
$\times$ Schimlinia $\mathrm{H} 2002-022-083$ & $1.0 \mathrm{a}$ & $1.0 \mathrm{a}$ & $1.5 \mathrm{~b}$ & $1.6 \mathrm{bc}$ & $1.6 \mathrm{~b}$ & $1.6 \mathrm{~b}$ & $1.6 \mathrm{bc}$ & $118.85 \mathrm{c}$ \\
$\times$ Schimlinia $\mathrm{H} 2002-022-084$ & $1.0 \mathrm{a}$ & $1.0 \mathrm{a}$ & $1.2 \mathrm{~b}$ & $1.6 \mathrm{bc}$ & $1.6 \mathrm{~b}$ & $1.6 \mathrm{~b}$ & $1.6 \mathrm{bc}$ & $116.05 \mathrm{c}$ \\
$\times$ Gordlinia $\mathrm{H} 2004-024-008$ & $1.0 \mathrm{a}$ & $1.0 \mathrm{a}$ & $1.3 \mathrm{~b}$ & $1.3 \mathrm{c}$ & $1.3 \mathrm{~b}$ & $1.3 \mathrm{~b}$ & $1.3 \mathrm{bc}$ & $103.35 \mathrm{c}$ \\
S. wallichii & $1.0 \mathrm{a}$ & $1.0 \mathrm{a}$ & $1.0 \mathrm{~b}$ & $1.0 \mathrm{c}$ & $1.0 \mathrm{~b}$ & $1.0 \mathrm{~b}$ & $1.0 \mathrm{c}$ & $84.00 \mathrm{c}$ \\
S. khasiana & $1.0 \mathrm{a}$ & $1.0 \mathrm{a}$ & $1.0 \mathrm{~b}$ & $1.0 \mathrm{c}$ & $1.0 \mathrm{~b}$ & $1.0 \mathrm{~b}$ & $1.0 \mathrm{c}$ & $84.00 \mathrm{c}$ \\
\hline
\end{tabular}

${ }^{\mathrm{z}} 1$ = healthy, 2 = initial symptoms (flagging of new growth, chlorosis), $3=$ severe symptoms (wilting, necrotic leaves), $4=$ dead.

${ }^{y}$ AUDPC calculated using all ratings taken twice a week over a period of 12 weeks.

${ }^{x}$ Values are mean, $\mathrm{n}=10$. Means followed by the same letter, within a column, are not significantly different, $P \leq 0.05$.

Schima species, and the hybrid taxa. Resistance in the hybrid taxa was similar to their more resistant parental genus, i.e., Gordonia or Schima.

Although Franklinia, Gordonia, Schima, and their hybrids are all closely related, it is not surprising that significant differences exist in their susceptibility to $P$. cinnamomi. Differences in susceptibility to $P$. cinnamomi among closely related species have been reported in Rhododendron L. (Benson, 1980; Hoitink and Schmitthenner, 1974; Krebs and Wilson, 2002), Vaccinium L. (Clark et al., 1986), Banksia L.f. (McCredie et al., 1985), and Abies Mill. (Benson et al., 1998; Hinseley et al., 2000). Even cultivars, clones, or provenances of the same species have shown significant differences in susceptibility, as in the case of Pinus radiata D.Don (Butcher et al., 1984), Persea americana Mill. (Gabor et al., 1990), Abies fraseri (Frampton and Benson, 2004), and Eucalyptus marginata Sm. (Stukely and Crane, 1994).

Previous studies have suggested that resistance to $P$. cinnamomi may be partially recessive (Clark et al., 1986) and controlled by multiple genes (Butcher, 1987; Stukely and Crane, 1994). Resistance to the pathogen in this experiment appears instead to be at least partially dominant, because all hybrid taxa expressed a level of resistance similar to that of the more resistant parent.

The results of this study show that sources of resistance to $P$. cinnamomi do exist in the tribe Gordonieae and that resistance can be successfully transmitted to hybrid progeny. This information will aid ongoing breeding efforts to combine the desirable ornamental traits of these taxa with a high level of resistance to $P$. cinnamomi. In addition, an effective protocol for the quick screening for $P$. cinnamomi resistance in this tribe has been established and can be applied to hybrids developed in the future.

\section{Literature Cited}

Benson, D.M. 1980. Resistance of evergreen hybrid azaleas to root rot caused by Phytophthora cinnamomi. Plant Dis. 64:214-215. 
Benson, D.M. 1990. Landscape survival of fungicidetreated azaleas inoculated with Phytophthora cinnamomi. Plant Dis. 74:635-637.

Benson, D.M., L.E. Hinesley, J. Frampton, and K.C. Parker. 1998. Evaluation of six Abies spp. to Phytophthora root rot caused by Phytophthora cinnamomi. Biol. Cult. Tests Control of Plant Dis. 13:57.

Butcher, T.B. 1987. Genotypic variation in resistance to Phytophthora cinnamomi in the Pinus radiata species. University of Western Australia, Perth, Australia. MS (Agr.) Thesis.

Butcher, T.B., M.J.C. Stukely, and G.W. Chester. 1984. Genetic variation in resistance of Pinus radiata to Phytophthora cinnamomi. For. Ecol. Mgt. 8:197-220.

Clark, J.R., J.N. Moore, and A.D. Draper. 1986. Inheritance of resistance to Phytophthora root rot in highbush blueberry. J. Amer. Soc. Hort. Sci. 111:106-109.

Dirr, M.A. 1998. Manual of woody landscape plants: Their identification, ornamental characteristics, culture, propagation and uses. 5th ed. Stipes Publishing, Champaign, IL.

Erwin, C.D. and O.K. Ribeiro. 1996. Phytophthora diseases worldwide. Amer. Phytopathol. Soc., St. Paul, MN.

Frampton, J. and D.M. Benson. 2004. Phytophthora root rot mortality in Fraser fir seedlings. HortScience 39:1025-1026.

Fry, J.T. 2000. Franklinia alatamaha, a history of that "very curious" shrub. Bartram Broadside (Spring 2000):1-24.
Gabor, B.K., F.B. Guillemet, and M.D. Coffey. 1990. Comparison of field resistance to Phytophthora cinnamomi in twelve avocado rootstocks. HortScience 25:1655-1656.

Griffiths, M. 1994. Index of garden plants. Macmillan, London, UK.

Hinseley, L.E., K.C. Parker, and D.M. Benson. 2000. Evaluation of seedlings of Fraser, momi, and Siberian fir for resistance to Phytophthora cinnamomi. HortScience 35:87-88.

Hoitink, H.A.J. and A.F. Schmitthenner. 1974 Resistance of rhododendron species and hybrids to Phytophthora root rot. Plant Dis. Rpt. 58:650-653.

Koslow, G. and J.L. Peterson. 1980. Phytophthora root and crown rot of Franklinia trees. J. Arboriculture 6:89-92.

Krebs, S.L. and M.D. Wilson. 2002. Resistance to Phytophthora root rot in contemporary rhododendron cultivars. HortScience 37:790792.

Krüssman, G. 1986. Manual of cultivated broadleaved trees and shrubs. Timber Press, Portland, OR.

Liberty Hyde Bailey Hortorium. 1976. Hortus third: A concise dictionary of plants cultivated in the United States and Canada. Macmillan, New York, NY.

Luna, I. and H. Ochoterena. 2004. Phylogenetic relationships of the genera of Theaceae based on morphology. Cladistics 20:223-270.

McCredie, T.A., K.W. Dixon, and K. Sivasithamparam. 1985. Variability in the resistance of
Banksia L.f. species to Phytophthora cinnamomi Rands. Aust. J. Bot. 33:629-637.

Prince, L.M. and C.R. Parks. 2001. Phylogenetic relationships of Theaceae inferred from chloroplast DNA sequence data. Amer. J. Bot. 88:2309-2320.

Ranney, T.G., T.A. Eaker, P.R. Fantz, and C.R. Parks. 2003. $\times$ Schimlinia floribunda (Theaceae): A new intergeneric hybrid between Franklinia alatamaha and Schima argentea. HortScience 38:1198-1200.

Ranney, T.G. and P.R. Fantz. 2006. ×Gordlinia grandiflora (Theaceae): An intergeneric hybrid between Franklinia alatamaha and Gordonia lasianthus. HortScience 41:1386-1388.

Shaner, G. and R.E. Finney. 1977. The effect of nitrogen fertilization on the expression of slowmildewing resistance in Knox wheat. Phytopathol. 67:1051-1056.

Stukely, M.J.C. and C.E. Crane. 1994. Genetically based resistance of Eucalyptus marginata to Phytophthora cinnamomi. Phytopathology 84:650-656.

Tsou, C. 1997. Embryology of the Theaceae-Anther and ovule development of Camellia, Franklinia, and Schima. Amer. J. Bot. 84:369-381.

Yang, S.-X., J.-B. Yang, L.-G. Lei, D.-Z. Li, H. Yoshino, and T. Ikeda. 2004. Reassessing the relationships between Gordonia and Polyspora (Theaceae) based on the combined analyses of the molecular data from the nuclear, plastid, and mitochondria genomes. Plant Syst. Evol. 248:45-55. 